\title{
KEARIFAN TEMPATAN ORANG MELAYU: REFLEKSI MELALUI HIKAYAT PELANDOK JENAKA
}

\section{(Reflections of Local Genius in Hikayat Pelandok Jenaka)}

\author{
Sakinah Abu Bakar \\ sakinah@usm.my
}

Pusat Pengajian Pendidikan Jarak Jauh, Universiti Sains Malaysia.

\begin{abstract}
Abstrak
Isu kemanusiaan menjadi subjek yang dominan dalam karya kesusasteraan kerana manusia dan kemanusiaan merupakan suatu gabungan elemen fizikal dan mental yang cukup kompleks. Kompleksiti itu terjadi kerana amalan kebudayaan yang berbeza mengikut negara, kaum, agama serta kepercayaan yang kemudiannya membentuk cara hidup, personaliti dan perwatakan. Kemanusiaan adalah nilai yang universal yang dapat digarap dan dimanfaatkan sebagai impak bermakna dalam kehidupan manusia daripada pembacaan terhadap genre kesusasteraan. Nilai ini turut dapat digarap dalam cerita binatang yang menjadi salah satu cabang cerita rakyat. Cerita binatang merupakan sisipan tindak tanduk manusia dan kemanusiaan menerusi watak-watak binatang. Watak dan perwatakan tersebut digarap oleh pengarang masa lampau sebagai pernyataan kemanusiaan dengan begitu halus dan menarik. Konflik antara watak-wataknya adalah paparan fenomena yang berlaku dalam kehidupan sebenar manusia. Isu kepimpinan, konflik dan penyelesaian dipersembahkan dalam penceritaan yang bersahaja, ringan dan berunsur lelucon. Unsur lelucon disaring dengan pemikiran jernih yang menyajikan kebijaksanaan dan ilmu pengetahuan khususnya berkaitan fenomena alam sekitar. Artikel yang membincangkan kisah-kisah pilihan daripada Hikayat Pelandok Jenaka ini memaparkan konflik-konflik yang terjadi dalam kelompok masyarakat binatang serta kaedah penyelesaiannya sebagai refleksi kearifan masyarakat Melayu lampau.
\end{abstract}


Kata kunci: cerita binatang, refleksi kearifan Melayu, Hikayat Pelandok Jenaka, penyelesaian konflik

\begin{abstract}
Human issues are the dominant subjects in literary works because the human element and humanity are related in complex ways. This complexity is due to different cultural practices according to one's country, ethnicity, religion and belief, which in turn shape one's way of life, personality and character. Literature, on the whole, attempts to reflect the differences, uniqueness and complexities of people's lives. Humanity, however, is a universal value that has a meaningful impact on the lives of people, which can be gleaned from reading literary works. This universal value can be discerned in animal fables, which are one branch of folk tales. Animal fables reflect human actions through animal characters. Ancient storytellers used such characters and characterizations as subtle and interesting expressions of humanity. Conflicts between characters demonstrate phenomena that really take place in human life. Issues such as leadership, and conflict and resolution are presented in a light, casual and comedic style. The comedic element Clear thinking filters the comedic element and provides knowledge, especially concerning natural phenomena. This article discusses several fables from the Hikayat Pelandok Jenaka that deal with conflicts within the community and their methods of resolution in order to reflect the knowledge of the Malay community of the past.
\end{abstract}

Keywords: animal fable, reflections of Malay knowledge, Hikayat Pelandok Jenaka, conflict resolution

\title{
PENDAHULUAN
}

Cerita binatang termasuk salah satu cabang cerita rakyat. Mengapa cerita ini dikategorikan sebagai cerita binatang? Pengkategoriannya sedemikian kerana cerita berkenaan memaparkan binatang sebagai watak utama. Watak yang dibangunkan dalam cerita binatang merupakan gambaran perwatakan manusia. Watak dan perwatakan tersebut dibangunkan oleh pengarang masa lampau dalam cara yang amat menarik. Banyak persoalan kemanusiaan dijalinkan menerusi kisah-kisah tersebut. Soal kepimpinan, konflik dan penyelesaian merupakan salah satu cabang penceritaan yang sering bersatu dalam suatu penceritaan yang bersahaja, ringan dan berunsur lelucon. Namun, jika diteliti dengan rinci, konflik masyarakat, persoalan kepimpinan, fenomena masyarakat setempat secara fizikal dan mental begitu menonjol. Unsur lelucon disaring dengan pemikiran yang jernih yang menyajikan 
kebijaksanaan dan ilmu pengetahuan khususnya berkaitan fenomena alam sekitar. Makalah ini akan membincangkan beberapa kisah daripada Hikayat Pelandok Jenaka yang memaparkan kemahiran penyelesaian konflik yang disalurkan melalui hikayat berkenaan. Di samping itu, sisipan pengajaran, amanat, pandang alam akan turut ditinjau dalam cerita berkenaan.

Hal yang amat menarik ialah kaedah yang diguna pakai oleh pengarang yang mempamerkan kemahiran penyelesaian konflik sehingga akhirnya boleh menjadi peluang baik terhadap kelompok masyarakat yang berhadapan dengan konflik berkaitan. Dalam konteks Hikayat Pelandok Jenaka penceritaan dan paparan watak dan perwatakan menggambarkan hal ehwal kehidupan masyarakat manusia. Sikap dan perlakuan manusia terselindung di sebalik watak dan perwatakan binatang. Dengan cara ini pengarang tidak perlu gusar tentang persepsi khalayak secara langsung kerana kisah yang ditonjolkan itu tidak menyentuh mana-mana pihak secara terbuka. Yang lebih penting daripada itu ialah sifat genius di sebalik perlakuan dan tindakan watak yang dipaparkan yang dapat dianggap mewakili suara cendekiawan Melayu lama dengan ekspresi dan refleksi yang santai dan bersahaja. Kaedah yang diguna pakai oleh pengarang Melayu lampau ini merupakan suatu kaedah yang bijak dan dapat diterima oleh masyarakat Melayu semasa. Hal ini sangat sinonim dengan budaya masyarakat Melayu yang sering menyampaikan amanat menerusi bahasa yang halus dan dalam cara yang sopan dan terhormat. Sarana pengarang memaparkan kebijaksanaan pemikiran masyarakat Melayu lama ini wajar diketengahkan sebagai wahana pendidikan. Hal seumpamanya amat digalakkan memandangkan konflik yang terjadi dalam masyarakat merupakan hal yang normal dan menjadi sebahagian daripada bentuk perhubungan yang sihat. Sebahagian daripada konflik itu tercetus kerana sebab-sebab yang asasi; yang menyentuh soal sahsiah, amanah, kepercayaan, amalan hidup dan banyak lagi aspek kehidupan yang bersifat spiritual.

Sastera rakyat berbentuk naratif seperti cerita binatang ini berfungsi sebagai hiburan, pendidikan, propaganda, kritikan dan kepercayaan. Perbezaan taraf hidup dan sosial antara masyarakat mewujudkan kritikan atau protes. Cerita rakyat merupakan wacana masyarakat tradisi untuk melahirkan perasaan tidak puas hati mereka terhadap sistem pemerintahan. Cerita legenda umpamanya melahirkan wira bangsa yang terdiri daripada golongan masyarakat kebanyakan. Wira ini menjadi kebanggaan rakyat zaman-berzaman. Cerita yang terkumpul dalam cerita rakyat seperti cerita jenaka, binatang, teladan dan hantu sangat penting untuk memberikan hiburan, pengajaran, kritikan dan kepercayaan kepada anggota masyarakat. Cerita ini dapat membimbing 
masyarakat ke arah melakukan kebaikan dan menolak kemungkaran sesuai dengan ajaran dan sistem nilai masyarakat silam.

Glosari Istilah Kesusasteraan (1988) menerangkan bahawa cerita rakyat tergolong dalam sastera rakyat berbentuk naratif yang merupakan cerita rekaan yang disampaikan secara lisan dari satu generasi ke satu generasi. Cerita rakyat merupakan tinggalan nenek moyang yang tidak diketahui penciptanya dan dianggap sebagai kepunyaan bersama. Corak masyarakat yang melahirkan cerita rakyat ini ialah masyarakat kecil yang hampir tertutup dan terpencil seperti masyarakat tani atau nelayan yang tinggal di pedalaman atau di desa. Cerita yang tergolong dalam cerita rakyat ialah cerita penglipur lara, binatang, jenaka, asal usul dan hantu. Cerita rakyat Melayu seperti cerita binatang, jenaka dan penglipur lara mengandungi falsafah pengajaran yang tinggi di samping unsur hiburan yang berkesan. Keadaan ini disebabkan hubungan yang erat dengan masyarakat bertamadun tinggi sejak lama dahulu, iaitu dengan tamadun Islam melalui kesusasteraan Arab dan Parsi serta Hindu. Glosari Istilah Kesusasteraan (1988:47) mendefinisikan cerita binatang sebagai sejenis cerita rakyat yang juga dikenali sebagai cerita mergastua. Cerita binatang biasanya pendek dan watak-wataknya terdiri daripada binatang yang diberikan sifat manusia, berakal, boleh bercakap, dan sebagainya. Watak manusia, jika ada, hanya diberikan peranan kecil sahaja, kadang-kadang sebagai pemburu atau penggembala atau kadangkadang bersifat bodoh pula. Cara penyampaiannya adalah sederhana dari segi bahasa dan struktur cerita.

Cerita binatang ada hubungannya dengan cerita nabi-nabi, contohnya Nabi Sulaiman dan Nabi Noh yang diberikan mukjizat memahami bahasa binatang. Kemungkinan besar kaitan tersebut menyebabkan cerita binatang diminati oleh masyarakat Nusantara. Kisah yang berkisar satu jenis binatang disebut epik binatang. Pelanduk atau sang kancil dapat dianggap sebagai epik binatang. Antara yang telah dibukukan termasuklah Hikayat Pelandok Jenaka. Gelaran "Syah Alam di Rimba" pula menggambarkan kecerdikan binatang tersebut.

Menurut Muhammad Haji Salleh (2007:6) dalam tulisannya berjudul "Beberapa Catatan Pengalaman Sastera Lisan", sastera lisan tidak perlu dikaji untuk ceritanya sahaja. Konsep pengarang, teks, fungsi karya atau pencerita dapat dilihat dengan lebih jelas lagi dalam cerita lisan yang masyarakatnya terdedah kepada bentuk sastera yang lebih baharu, yang lebih cair hari ini. Genre atau jenis-jenis kecil cerita rakyat Melayu antara lain ialah cerita binatang yang dapat dibahagikan kepada pelbagai fungsinya, tetapi motif 
dasarnya ialah binatang seperti cerita-cerita sang kancil. Pemilihan binatang sebagai pelaku utama dalam cerita sebegini bertujuan memberi teladan, menerangkan asal usul kejadian, menghibur dengan perlakuan pintar binatang tertentu seperti sang kancil, atau bertujuan menyindir (Mohd Taib, 2007:302-03). Tale type merupakan motif dalam penceritaan sastera rakyat. Cerita binatang menyerlahkan kearifan tempatan. Yang terkenal dalam kalangan masyarakat Melayu ialah cerita sekitar sang kancil, iaitu watak haiwan cerdik yang menepati motif trickster. Pemilihan motif ini lazimnya dibuat daripada pemerhatian dan pengamatan masyarakat Melayu terhadap sifat binatang berkenaan.

Mohd Taib (2007:304-06), dalam tulisannya "Sastera Rakyat/Lisan Melayu: Antara Pernyataan "Local Genius" dengan Ciri-ciri Kesejagatan" mempersoalkan sejauh mana cerita rakyat Melayu memanifestasikan kearifan tempatan dan juga menggambarkan ciri kesejagatan, iaitu unsur yang dikongsi bersama atau yang mencerminkan penerimaan, pinjaman atau saduran daripada kesusasteraan luar. Local genius atau kearifan tempatan merupakan kebijaksanaan setempat yang mencetuskan dan mencorakkan sastera rakyat Melayu, dan cara pernyataan itu dapat dilihat. Pengalaman yang telah dilalui oleh orang Melayu, terutama pertembungan peradaban setempat dengan peradaban asing, perlu diambil kira untuk menilai cara pengalaman sepanjang zaman itu meninggalkan kesan kepada cerita rakyat Melayu seperti yang diketahui pada masa kini. Yang lebih penting dalam kajian seumpama ini adalah dengan membuat sorotan berimbang antara unsur luar yang hadir dengan kebijaksanaan setempat yang lahir daripada keupayaan untuk mengisi kehendak tempatan. Bagi beliau, kearifan tempatan dalam kepustakaan Melayu tradisi, khususnya genre sastera rakyat merupakan sesuatu yang bersifat sementara dan belum muktamad.

Noriah (2007:459) dalam tulisannya bertajuk "Sastera Lisan: Rencah Warisan dalam Pembentukan Tamadun dan Budaya" pula menjelaskan bahawa "sastera lisan, iaitu seluruh korpus teks berselerak di ruang maya, yang berlegar daripada mulut pencerita kepada telinga pendengar, ialah bentuk khazanah yang amat cair dan rapuh sifatnya. Rapuh kerana sastera lisan lenyap sebaik-baik sahaja diujarkan kecuali yang sempat tergarap oleh ingatan pendengarnya; cair kerana sastera lisan tidak dapat dibekukan dalam bentuk yang kaku atau abadi kecuali dalam petak-petak ingatan pembawa tradisi itu. Namun, sastera lisan merupakan khazanah silam yang amat bernilai bukan sahaja nilai sasteranya tetapi juga nilai dokumentarinya. Sebagai hasil kreatif manusia tradisional yang awal, sastera lisan membawa 
bersamanya seluruh perawakan dan perwatakan tamadun awal tersebut, termasuk pemikiran, pandang alam, adab, adat, dan segala rencah budaya leluhur. Berdasarkan gagasan dan penelitian para sarjana tersebut, maka kajian seumpama ini wajar terus diketengahkan untuk dijadikan pedoman kepada khalayak.

\section{PENGERITAN KONFLIK}

Konflik berasal daripada perkataan Latin "conflictus" yang merujuk situasi apabila terdapat pihak berusaha untuk melancarkan mogok secara kekerasan, juga keadaan yang membayangkan wujudnya ketidaksetujuan terhadap sesuatu perkara, pergeseran dan perselisihan antara ahli kumpulan. Kajian berkenaan konflik ini sering mendapat perhatian para sarjana dan penyelidik yang boleh diteliti daripada pelbagai disiplin ilmu seperti sosiologi, psikologi, sains politik, pengurusan dan juga komunikasi (Malike, 2008:4-5). Sementara itu, Abdullah dan Ainon (1997:130) menyatakan bahawa terdapat dua jenis konflik. Jenis pertama ialah konflik berpusat pada benda, perkara atau peristiwa, manakala jenis yang kedua pula ialah konflik perhubungan. Deutsch (1971) pula, seperti yang dipetik dalam Malike (2008:7) menyenaraikan lima jenis konflik, iaitu intrapersonal (dalam diri), interpersonal (antara individu), intrakelompok (dalam kelompok), interkelompok (antara kelompok) dan internasional (antarabangsa).

Sepanjang kehidupan ini, manusia sering dihidangkan dengan konflik sama ada kecil mahupun besar. Oleh itu, kita perlu bijak untuk menangani konflik bagi mengelak daripada berterusan sehingga boleh memburukkan lagi keadaan dan menjejaskan perhubungan. Dalam hal ini, kesan yang berlaku akibat konflik adalah pelbagai serta bergantung pada individu yang terlibat dengan konflik itu. Selain itu, turut dinyatakan bahawa konflik bukan sekadar membawa kesan negatif tetapi juga kesan positif sekiranya ditangani secara bijaksana (Md. Yadi, 2006:55). Konflik begitu kerap berlaku sehingga patut dianggap sebagai normal. Hal ini dikatakan demikian kerana perhubungan yang terjalin melibatkan individu yang memiliki pelbagai peribadi, emosi, idea, konsep diri dan macam-macam lagi (Abdullah dan Ainon, 1997:130). Berdasarkan pendapat Lewis A. Coser (1956:8), beliau melihat konflik sebagai perjuangan individu dan kelompok yang berkisar pada nilai dan kebimbangan terhadap kedudukan, persaingan untuk mendapatkan kuasa dan sumber yang terhad, yakni kecenderungan mereka untuk meneutralkan, merosakkan atau menghapuskan saingan mereka. Oleh itu, dapat dilihat bahawa 
ada tindakan positif dan negatif yang dibuat untuk menghadapi konflik yang terjadi. Dari sudut negatifnya, terdapat usaha untuk menghapuskan pesaing dan membinasakan mereka. Dari sudut positif pula, konflik yang tercetus membawa usaha pihak-pihak yang berkonflik untuk meneutralkannya demi kepentingan bersama melalui perundingan, persetujuan, tolak ansur, kerjasama dan perpaduan (Malike, 2008:7).

Daripada beberapa pengertian konflik yang telah dibincangkan, dapat dirumuskan bahawa konflik telah banyak mempengaruhi kehidupan manusia. Konflik tersebut merupakan suatu lumrah yang dianggap sebagai dugaan dan cabaran hidup. Untuk meredakan atau menyelesaikan sesuatu konflik, memerlukan kebijaksanaan yang khusus agar penyelesaiannya mampu membebaskan diri individu dan kumpulan manusia yang menghadapi situasi konflik tersebut tidak terus terperangkap dalam kemelut yang merugikan. Oleh itu, konflik harus ditangani dengan rasional supaya memberikan kesan yang positif kepada pihak yang berkonflik. Walaupun konflik secara tidak langsung memberikan gambaran negatif yang boleh membawa bencana dalam kehidupan manusia tetapi dengan kaedah pengendalian dan pengurusannya yang sesuai akan mendatangkan kebaikan kepada pihak yang berkonflik. Dalam konteks konflik yang membabitkan dua kumpulan manusia, langkah penyelesaian akan memberikan impak yang positif kepada kedua-dua belah pihak.

\section{Konflik antara Kelompok atau Kumpulan (Intergroup Conflict)}

Konflik wujud secara semula jadi dan sesuatu keadaan yang tidak dapat dielakkan. Dalam persekitaran yang memiliki pelbagai watak dan ragam masyarakatnya sememangnya menyerlahkan lagi konflik dalam kehidupan. Di samping itu, konflik juga boleh mendatangkan kesan buruk kepada pihak yang mengalaminya seperti kegagalan, kemusnahan, kekecewaan dan sebagainya. Konflik jenis ini merujuk "... an overt expression of tension between the goal or concern of one party and those of another". Konflik interkelompok yang dikemukakan oleh Tony Belak (1998) merupakan suatu perkara yang lumrah dalam kumpulan atau kelompok. Konflik ini juga berlaku disebabkan oleh keadaan saling bergantungan untuk melakukan kerja, kepelbagaian matlamat, perbezaan dalam persepsi dan peningkatan permintaan kepada kepakaran. Malah, ahli kumpulan memainkan peranan dalam permulaan konflik antara kelompok (Malike, 2008:85-86). Wilf H. Ratzburg (2003) mengklasifikasikan punca konflik antara kumpulan kepada empat, iaitu kepentingan yang bertentangan, persaingan untuk mencapai 
matlamat, perbezaan budaya dan perbezaan kuasa. Menurut Gary Bornstein (2003), konflik antara kumpulan umumnya melibatkan konflik kepentingan dalam persaingan kumpulan-kumpulan, malah ahli teori konflik menyatakan bahawa konflik ini adalah rasional, yakni kumpulan itu mempunyai matlamat yang tidak sehaluan dan mereka saling bersaing untuk mendapatkan sumber yang terhad. Persaingan antara kumpulan ini juga boleh berlarutan sehingga melibatkan ahli kumpulan (Malike, 2008:103).

Kesan terhadap konflik antara kumpulan seperti yang dikatakan oleh Belak (1998), disebabkan oleh perubahan yang berlaku dalam kedua-dua kumpulan yang berkonflik. Dalam kumpulan, ahli kumpulan biasanya melupakan perbezaan antara individu dalam usaha bersatu untuk menentang pihak lain, tumpuan mereka pula adalah terhadap tugas yang diberikan. Di samping itu, kumpulan menjadi lebih cekap dan berkesan jika ahlinya bersatu dan pada masa yang sama akan mematuhi norma dalam sebuah kumpulan. Oleh hal yang demikian, penulisan ini mengupas konflik yang terdapat dalam Hikayat Pelandok Jenaka dan cuba mengenal pasti kaedah yang digunakan untuk mengatasi konflik tersebut.

Secara ringkasnya, konflik dalam teks ini melibatkan dua kumpulan yang terdiri daripada binatang di rimba, iaitu antara kumpulan yang mempunyai matlamat untuk menunjukkan kekuatan yang dimiliki dengan satu lagi kumpulan binatang yang lebih lemah tetapi mendapat bantuan pakar, iaitu pelanduk jenaka atau lebih dikenali sebagai Tuan Syeikh Alam di Rimba. Konflik yang tercetus dalam kalangan penghuni rimba ini berpunca daripada dendam dan sikap pihak yang tidak berpuas hati dengan pihak yang satu lagi serta sikap angkuh segolongan pihak yang cuba mencetuskan persaingan menggunakan kekuatan fizikal mereka untuk mencabar dan mengganggu keamanan kumpulan binatang terbabit. Keadaan ini seterusnya menyemarakkan lagi konflik untuk mencapai matlamat tertentu. Bagi menangani masalah yang berlaku antara kumpulan binatang yang berkonflik ini, pengarang menggunakan watak Pelanduk sebagai tokoh terkenal dan bijak. Hal ini secara tidak langsung menggambarkan kearifan pengarang Melayu dahulu melalui penggunaan watak binatang di samping memberikan pengajaran kepada khalayak. Perkara ini akan dibincangkan dengan lebih terperinci lagi dalam ruangan perbincangan. 


\section{Konflik dan Penyelesaian dalam beberapa Kisah Pilihan daripada Hikayat Pelandok Jenaka}

Hikayat Pelandok Jenaka diterbitkan oleh Pejabat Karang-Mengarang, Jabatan Pelajaran Persekutuan Tanah Melayu, Kuala Lumpur dan dicetak oleh Gudang Chap Malaya Publishing House Limited, Singapore pada tahun 1955. Cetakan pertama teks ini berjumlah 25000 naskhah. Lapan buah cerita dalam teks ini dipetik daripada "Hikayat Pelandok" (Malay Literature Series, No.13), 20 buah cerita lagi diasingkan dalam tahun 1953 dan diberi judul "Hikayat Sang Kancil". Hikayat Pelandok Jenaka memuatkan lapan buah cerita yang masing-masing berjudul "Harimau Berdamai dengan Kambing", "Pelandok Jenaka Menipu Gergasi”, "Sang Singa Tertakluk kepada Pelandok Jenaka", "Shaikh "Alam Berbenteh dengan Raja Gajah", "Sang Rangkak Kena Hukum", "Pelandok Jenaka Berlawan Minum Ayer dengan Rakyatnya", "Shaikh Alam Berlawan dengan Raksasa" dan "Gajah Berperang dengan Semut". Kisah ini ditunjangi oleh watak pelanduk jenaka yang diberi gelaran Tuan Syeikh Alam di Rimba dan dianggap sebagai pemimpin yang hebat, dihormati dan disegani oleh penghuni rimba kerana kebijaksanaannya. Hal ini digambarkan melalui tindak tanduk, buah fikiran dan tipu muslihat yang digunakan dalam menyelesaikan masalah masyarakat di rimba raya di bawah pimpinannya. Dalam perbincangan ini selanjutnya persoalan konflik dan penyelesaiannya akan diberikan perhatian dalam tiap-tiap kisah yang dikutip daripada teks berkaitan.

Dalam kisah "Harimau Berdamai dengan Kambing" digambarkan tipu muslihat watak Pelanduk yang menggelar dirinya sebagai Tuan Syeikh Alam di Rimba. Dia telah berpura-pura bertapa selama tiga tahun, tiga bulan dan tiga hari serta berjaya meyakinkan sekumpulan kambing dan harimau bahawa dia telah diberikan doa-doa mustajab oleh wali Allah untuk menghalang harimau daripada mengganggu kambing. Untuk membawa watak orang bertapa yang begitu lama tinggal dalam pertapaannya, maka muslihatnya ialah dengan melumurkan getah kayu ara pada kepala, janggut, misai, rambut dan keningnya agar kelihatan keputih-putihan. Dalam konteks ini, nilai kepimpinan dipaparkan melalui personaliti atau rupa diri. Untuk menakutkan harimau pula, Pelanduk telah menggunakan helah, iaitu meminta kambing memakan buah lakum ${ }^{1}$ yang masak kemerah-merahan. Apabila kambing memakan buah tersebut maka mulut, janggut dan misai seperti berlumuran darah disebabkan warna air buah lakum tersebut. Rupa kambing seperti berlumuran darah amat menakutkan anak-anak harimau yang dihantar untuk meninjau keadaan kambing. Setelah pelanduk berjaya menggambarkan 
kekuatan kambing kepada harimau maka kedua-dua pihak bersetuju berdamai dan tidak lagi bermusuhan. Mereka dipertemukan secara berhadap-hadapan dan masing-masing bersetuju memilih jalan damai. Diperlihatkan bahawa pengarang menggunakan pengetahuannya berkenaan dengan getah kayu ara dan buah lakum yang tumbuh meliar di hutan untuk menampakkan kealiman pelanduk dan kehebatan kambing. Hal ini sekali gus menggambarkan pelanduk sebagai pemikir yang handal melalui idea melumurkan getah kayu ara yang berwarna putih bagi menyamar sebagai petapa tua supaya kelihatan warak dan meyakinkan sesiapa sahaja yang melihatnya. Buah lakum pula yang mengeluarkan cairan merah seumpama darah apabila dimakan pula merupakan strategi penyelesai masalah menggunakan personaliti dan kreativiti yang terhasil daripada sumber alam yang bermanfaat dalam persekitaran.

Apakah yang dapat dipelajari di sebalik kisah harimau dan kambing ini? Pertama, dengan cara tipu helah, pelanduk berjaya meyakinkan harimau dan kambing tentang kewibawaannya sebagai pemimpin yang cerdik. Watak kepimpinan diiringi dengan pemikiran sehingga dapat mempengaruhi pihak yang sangat kuat yang diwakili oleh watak harimau. Kelompok masyarakat yang lebih lemah diajar membuat tipu helah demi menyelamatkan diri daripada menjadi mangsa keganasan pihak yang lebih kuat. Mereka bukan saja diyakinkan tentang kekuatan dan kelebihan masing-masing malah dianjurkan untuk berdamai secara berhemah. Isu kepimpinan merujuk personaliti pemimpin sehingga berjaya memainkan peranannya sebagai jaksa pendamai. Apakah yang mendorong pengarang menzahirkan kisah kebijaksanaan pelanduk ini? Apakah situasi berkonflik terjadi dalam masyarakat Melayu lama sehingga timbul idea pengisahan ini sebagai paparan simbolik untuk tatapan umum?

Seperti kisah pertama yang membabitkan dua pihak bertentangan, maka kisah kedua yang berjudul "Pelandok Jenaka Menipu Gergasi" juga menggambarkan konflik antara dua pihak, iaitu antara gergasi dan binatang lain. Kisah bermula daripada keluh-kesah seladang, badak, landak, rusa, kijang dan binatang lain tentang keganasan gergasi yang memakan kaum keluarga mereka sehingga tiada lagi ruang untuk bermain bagi anak-anak mereka yang terselamat daripada menjadi mangsa gergasi. Bagi individu yang dianggap sebagai pemimpin yang bijaksana, pelanduk dimaklumkan tentang krisis yang dihadapi oleh binatang tersebut. Pelanduk menyelesaikan masalah tersebut dengan lidah dan perbuatannya; dengan menipu gergasi mengatakan bahawa dunia akan kiamat: 
... Maka pelandok itu pun dudok-lah di tengah jalan sambil mengali-gali lubang dan berseru-seru katanya, "Wahai anak-ku dan isteri-ku, marilah masok ka dalam tanah, kerana aku dengar khabar daripada wali Allah yang keramat bahawa hari ini dunia akan kiamat dan langit dan bumi akan runtoh."

(Hikayat Pelandok Jenaka, 10)

Setelah berjaya meyakinkan gergasi tentang kedatangan hari kiamat itu, maka gergasi pun dengan sukarela mengali lubang sendiri untuk masuk bersembunyi di dalamnya. Setelah badan gergasi tertanam sehingga paras kepala, pelanduk pun menendang kepala gergasi disaksikan oleh binatang lain. Maka tersebarlah berita tentang tindakan pelanduk sebagai pemimpin yang cerdik. Nampaknya dalam kisah ini penyelesaian terhadap konflik yang dihadapi dilaksanakan dalam cara berbeza. Musuh dihapuskan dengan tipu daya dan tidak diberi peluang berdamai. Dalam hal ini, pengarang menggunakan strategi penyelesaian konflik menang-kalah. Pendekatan ini merupakan penyelesaian ke arah pembaikan yang cepat. Menurut Edward Glassman (1991), strategi ini menyetujui atau membenarkan satu pihak yang berkonflik untuk memenangi konflik yang berlaku atas kegagalan pihak lain (Malike, 2008:147). Inilah yang terjadi kepada konflik pelanduk-gergasi apabila diperlihatkan kemenangan pelanduk dan kekalahan gergasi sebagai penamat konflik antara mereka.

Sementara itu, episod "Sang Singa Tertakluk kepada Pelandok Jenaka" turut mengisahkan pertembungan konflik antara dua kuasa, iaitu raja singa dan pelanduk jenaka yang masing-masing memiliki pengaruh yang kuat dalam kalangan penghuni rimba. Kisah bermula apabila raja beruang mempersembahkan buah asam sebagai tanda penghormatan kepada Pelandok. Keadaan ini telah mencetuskan perasaan dengki dan tidak puas hati raja kera terhadap pelanduk kerana berasakan yang pelanduk terlalu dimuliakan oleh penghuni rimba. Konflik bertambah besar apabila raja kera mahu membalas dendam terhadap raja beruang dan Serigala yang telah membunuh rakyat dan anak isterinya. Pembunuhan tersebut terjadi kerana raja kera enggan tunduk kepada pelanduk.

Sikap raja singa yang begitu angkuh kerana berasa dirinya gagah dan kuat. Dia sering merendahkan keupayaan pelanduk yang bertubuh kecil. Hal ini telah mendorongnya meluaskan kuasa terhadap penghuni rimba dengan cara beradu tenaga sekali gus memenuhi impiannya untuk mengambil alih tempat pelanduk sebagai pemerintah di rimba. Walau bagaimanapun, raja 
singa dapat dikalahkan dengan mudah oleh buah fikiran dan kebijaksanaan pelanduk:

Maka Tuan Shaikh 'Alam di-Rimba pun segera-lah melompat serta dengan pantas-nya seperti kilat tiada sempat di-lihat lagi laku-nya itu, kerana tubohnya sangat kechil dapat lulus ka-sabelah sa-olah-olah roboh-lah kayu itu di-langgar-nya. Kemudian di-ambil-nya buah jala-jala tu sa-biji yang tiada bersemut, lalu di-makan-nya.

... Maka Raja Singa pun segera-lah melompat dan daripada sangat derasnya ia melompat itu, ia pun tersepit-lah pada kayu yang empat berapit itu kemudian di-ambil-nya buah jala-jala yang bersemut tu lalu di-makan-nya. Apa-tah lagi! Mabok-lah ia terguling-guling dan tiada-lah dapat keluar lagi.

(Hikayat Pelandok Jenaka: 22-23)

Petikan di atas menceritakan kebijaksanaan pelanduk membuat helah untuk mengalahkan raja singa, iaitu dengan cara melompat sepohon kayu yang terlintang dan kemudian memakan sebiji buah jala-jala. Tanpa disedari oleh raja singa, sebiji buah jala-jala yang ditinggalkan oleh pelanduk telah diisi dengan semut.

Pelanduk tidak menggunakan cara yang rumit bagi memenangi cabaran tersebut kerana padanya adalah cukup dengan menggunakan pemikirannya sahaja kerana sedar keupayaan fizikalnya tidak setanding dengan raja singa. Kekalahan raja singa dalam pertandingan tersebut menyebabkan diri dan keseluruhan rakyatnya ditakluk di bawah kuasa pelanduk. Musuh dalam kisah ini berjaya ditawan dengan mudah sehingga dapat membentuk jalan perdamaian antara dua pihak setelah raja singa akur dengan kehebatan pelanduk sebagai pemimpin yang hebat dan disegani.

Di samping itu, kepimpinan pelanduk jelas dapat dilihat melalui penghormatan dan sanjungan yang diberikan oleh setiap penghuni rimba kerana kebijaksanaan dan kewarakan pelanduk sebagai Tuan Syeikh Alam di Rimba. Hal ini ternyata melayakkan dirinya menjadi pemimpin yang pandai menyelesaikan konflik yang boleh mencetuskan bencana dan perbalahan besar kepada rakyatnya. Malah, sifat pemimpin yang bertanggungjawab akan mencari jalan penyelesaian terbaik tanpa mengorbankan nyawa dan ketenteraman rakyatnya. Hal ini berkaitan dengan proses menguruskan konflik, iaitu melalui kemahiran pelanduk dalam membuat muslihat dan tipu daya bagi melemahkan lawannya. Demi melihat rakyatnya hidup sejahtera, pelanduk berusaha mengelak daripada mendatangkan kebinasaan terhadap 
rakyat kedua-dua pihak dalam konflik antara mereka. Hal ini dinyatakan dalam petikan berikut:

Maka sahut Pelandok Jenaka, "Hai Raja Singa yang gagah lagi perkasa dan yang keras hati, jangan-lah kita mengadu-ngadu ra'ayat kita, tiada-lah harus kerana kita, rosak binasa kelak sakalian ra'ayat kita kedua pehak."

(Hikayat Pelandok Jenaka: 21)

Dalam kisah seterusnya berjudul "Shaikh "Alam Berbenteh dengan Raja Gajah" turut memaparkan adegan dan isi cerita yang seakan sama dengan kisah yang dibincangkan sebelum ini. Kisah bermula apabila raja kera mengadu nasib dan meminta perlindungan daripada raja gajah setelah keluarganya dibunuh oleh raja beruang dan raja serigala berikutan keengganannya mengakui ketuanan pelanduk sebagai raja di rimba. Lantaran itu, raja kera membangkitkan kemarahan raja gajah dengan kata-kata fitnah kononnya pelanduk telah menghina raja gajah. Raja gajah yang sememangnya tidak berpuas hati dengan kedudukan dan sanjungan segala isi rimba terhadap pelanduk menjadi bertambah tercabar lalu ingin menunjukkan kekuatannya. Maka, terjadilah peristiwa berbentehan antara raja gajah dengan pelanduk.

Bagi menyelesaikan konflik tersebut pelanduk menggunakan kebijaksanaannya, iaitu melalui tipu muslihat. Situasi ini diperlihatkan menerusi petikan yang berikut:

Maka ujar Tuan Shaikh “Alam di Rimba, “Ta' mengapa benteh-lah tuan-hamba dahulu," sambil mengunjorkan kaki-nya. Maka Raja Gajah pun segera-lah membenteh pelandok jenaka itu. Oleh Tuan Shaikh "Alam di-Rimba dilindongkan-nya kaki-nya itu di-balek tunggul teras itu, tidak di-lihat oleh Raja Gajah dan segala binatang itu dari sebab pantas-nya itu.

... Kemudian Tuan Shaikh 'Alam pun bersegera-lah membenteh Raja Gajah serta di-tikam-nya kaki Raja Gajah dengan kuku-nya yang tajam itu. Apatah lai! Raja Gajah pun berasa terlalu sakit kaki-nya hingga tiada terangkat lagi oleh bisa-nya itu...

(Hikayat Pelandok Jenaka: 33-34)

Dalam kisah ini juga, pelanduk diperlihatkan sebagai binatang yang pantas menyembunyikan setiap helahnya tanpa dapat disedari oleh pihak lawan. Binatang lain turut terpedaya apabila pelanduk bertindak menyembunyikan kakinya dengan pantas di sebalik tunggul kayu tanpa menunjukkan reaksi sakit, sedangkan raja gajah kelihatan menanggung kesakitan kerana berbenteh dengan 
tunggul pokok yang keras. Kebijaksanaan pelanduk telah membenamkan keegoan raja gajah yang sering meninggi diri dan bercakap besar terhadap binatang lain hanya disebabkan kekuatan fizikal yang dimilikinya. Dalam hal ini, ternyata penonjolan pelanduk sebagai watak yang dikurniakan kelebihan intelektual mengatasi watak binatang lain. Bahkan segala isi rimba memujimuji dan percaya pelanduk memperoleh kekuatan daripada baginda Ali, beroleh keberanian daripada Amir Hamzah dan kesaktian daripada wali Allah (Hikayat Pelandok Jenaka: 34). Berikutan kebijaksanaan dan kehebatan serta sanjungan yang tidak terhingga telah mewajarkan dirinya dipilih sebagai pemimpin yang disegani oleh segenap lapisan masyarakat rimba.

Pelanduk juga digambarkan memiliki sifat kepimpinan yang tinggi dan berwibawa melalui penampilan nilai murni dan sangat mementingkan prinsip perdamaian. Dia berjanji bahawa tidak akan dengki antara satu sama lain sekiranya menang mahupun kalah:

Ujar Shaikh 'Alam di-Rimba kepada Raja Gajah kata-nya, "Sekarang-lah kita berbenteh, dan hendak-lah kita berjanji di hadapan segala isi rimba ini bahawa walau siapa pun alah atau menang, jangan-lah sa-kali-kali berdengkidengkian."

(Hikayat Pelandok Jenaka: 32)

Penyelesaian konflik melalui perjanjian yang difikirkan oleh pelanduk ialah jalan terbaik demi menyelamatkan hubungan antara dua pihak terbabit seterusnya mengelak permusuhan daripada berpanjangan. Keadaan ini dapat dikaitkan dengan ciri konflik interpersonal, iaitu pertembungan dua pihak yang bertelagah berpunca daripada dendam. Situasi inilah yang dialami oleh pelanduk dan raja gajah yang berkonflik hasil daripada dendam raja kera terhadap raja beruang dan raja serigala lantas mengheret sekali rasa dendamnya terhadap pelanduk sebagai raja di rimba sehingga berjaya menghasut raja gajah menggunakan kekuatannya untuk mencabar kewibawaan pelanduk. Akan tetapi, dengan strategi pengurusan konflik yang berkesan bagi menghalang konflik yang negatif melalui syarat atau perjanjian yang merupakan suatu cara pengendalian bagi melemahkan kesannya jika konflik masih terus berlaku (Malike, 2008:153-54). Dalam peristiwa ini, raja gajah dan pelanduk masing-masing harus akur menerima kekalahan selain diingatkan supaya tidak saling berdengkian yang secara tidak langsung mengelak berlakunya konflik. Akhirnya, impak terhadap konflik tersebut berjaya dikendurkan dengan persetujuan terhadap janji yang dibuat. 
Seterusnya, kisah "Sang Rangkak Kena Hukum" menceritakan raja buaya yang tinggal di dalam sebuah sungai bernama Sungai Damasana. ${ }^{2}$ Perwatakan ganas raja buaya menyebabkan segala binatang di rimba yang minum atau mandi di sungai tersebut akan menjadi mangsa korbannya. Keadaan ini sangat mendukacitakan seluruh isi rimba. Setelah berbincang, binatang rimba masing-masing bersepakat untuk meminta pertolongan Tuan Syeikh Alam di rimba yang terkenal dengan kebijaksanaannya. Setelah menerima aduan permasalahan yang sangat merungsingkan itu, pelanduk memberikan idea dan menyuruh segala isi rimba mencari akar tuba lalu memotong akar tuba itu secara kecil-kecil lalu dicampakkan ke dalam Sungai Damasana. ${ }^{2}$ Akibatnya, buaya-buaya yang ada di dalam sungai itu timbul kerana mabuk terkena akar tuba. Disebabkan sedih melihat rakyatnya terseksa, raja buaya mengakui kesilapannya dan memohon keampunan daripada Tuan Syeikh Alam di-rimba kemudian merayu agar dipulihkan segera daripada kesan mabuk itu. Pelanduk yang menjadi sanjungan setiap isi rimba memerintahkan raja gajah dan rakyatnya mengambil air daripada sungai di sebalik sebuah bukit untuk mengubati mabuk tersebut dengan menuang air ke dalam mulut raja buaya dan setiap rakyatnya:

Maka kata Tuan Shaikh “Alam di-Rimba, "Jikalau demikian muntah-kanlah ayer itu supaya semboh penyakit kamu itu." Maka sakalian buaya itu pun memuntahkan-lah ayer itu. Satelah sudah maka baharu-lah sihat tuboh-nya masing-masing kerana ayer mabok itu telah keluar.

(Hikayat Pelandok Jenaka, 43)

Kebijaksanaan pelanduk untuk menyelesaikan konflik menunjukkan kehebatan akal fikirannya dan pada masa yang sama mengelak daripada berlaku keganasan seperti saling berbunuh-bunuhan. Dalam kisah ini, konflik diselesaikan bukan secara pertandingan atau tipu muslihat tetapi hanya dengan menggunakan kepandaiannya mengeksploitasi keadaan demi mewujudkan keamanan. Pelanduk menghapuskan keganasan raja buaya melalui pengetahuan dan kearifannya berkenaan bahan-bahan yang diperoleh daripada tumbuhan semula jadi seperti akar tuba. Akar tuba yang dipotong kecil-kecil dicampakkan ke dalam sungai supaya dapat memabukkan raja buaya dan rakyatnya sebagai balasan kekejaman raja buaya yang menganiayai binatang lain. Oleh itu, jelas menunjukkan kepimpinan pelanduk sebagai raja rimba yang memiliki kebijaksanaan sekali gus menampilkan kearifan orang Melayu untuk menyelesaikan permasalahan tanpa pertumpahan darah. 
Dalam kisah "Pelandok Jenaka Berlawan Minum Ayer dengan Rakyatnya" pula mengisahkan keinginan pelanduk atau Tuan Syeikh Alam di Rimba menunjukkan kesaktiannya dengan mencabar seluruh isi rimba supaya berlawan minum air dengannya. Tuan Syeikh Alam di Rimba memulakan cabaran dengan meminum air sungai Dar-al-fasikin sewaktu air sungai surut. Binatang lain kelihatan kagum dengan kesaktiannya menghabiskan air sungai itu. Setelah air sungai mulai pasang, binatang itu menyahut cabaran meminum air sungai tersebut tetapi tiada perubahan dilihat kerana air sungai tidak juga surut tetapi semakin naik. Usaha memperdayakan binatangbinatang itu menampakkan lagi kehebatan pelanduk sebagai penguasa rimba yang tiada tandingannya daripada segi pemikiran. Malah, mereka percaya keajaiban pelanduk meminum air sungai sehingga kering bergantung pada doa mustajabnya sebagai Tuan Syeikh Alam di Rimba:

... Mereka pun berkata-lah, "Mustajab sunggoh do'a-nya Tuan Shaikh 'Alam di-Rimba ini, barang satu pun ta' pernah mungkir kapada-nya. Tidaklah 'ajaib ayer sungai yang banyak ini boleh habis di-minum-nya?"

(Hikayat Pelandok Jenaka: 46)

Pengarang menampilkan pelanduk sebagai pembuat tipu helah yang pintar di samping kecekapan serta keterampilan kepimpinannya sewaktu melaksanakan sesuatu rancangan atau menyelesaikan masalah. Hal ini ditambah pula dengan anggapan rakyatnya yang sentiasa memuliakannya sebagai wali Allah yang keramat, maka secara tidak langsung mewajibkan mereka mempercayai sepenuhnya setiap tindakan yang dilakukan meskipun dilihat mengambil kesempatan atas ketinggian akalnya untuk membodohkan rakyat semata-mata inginkan sanjungan.

Seperti juga kisah pertembungan antara pelanduk dengan lawannya yang lebih besar dan kuat seperti gergasi, raja singa, raja gajah dan raja buaya, kisah "Shaikh "Alam Berlawan dengan Raksasa" turut mengambil pendekatan yang hampir sama dalam menampilkan kebijaksanaan dan kehandalan Pelandok. Mengisahkan tentang masalah yang dihadapi oleh isi alam akibat kerakusan raksasa yang bertindak memakan semua ikan-ikan yang dikumpulkan oleh binatang di Sungai Tinam sehingga menyebabkan berlaku perbalahan antara sang seladang, sang harimau dan sang badak. Usaha untuk menghalang raksasa tersebut daripada memakan ikan tersebut telah menemui jalan buntu lalu memaksa mereka meminta pertolongan daripada Shaikh 'Alam di-Rimba. Bagi menyelesaikan masalah tersebut, 
Tuan Syeikh Alam di Rimba mendapat idea dengan menggunakan simpai, iaitu lingkaran atau gelang-gelang berbentuk bulat yang diperbuat daripada rotan. Setelah rancangan disusun rapi, raksasa datang meminta ikan daripada Tuan Syeikh Alam di Rimba yang pada waktu itu sedang membakar ikan. Raksasa kemudiannya diperdaya dengan menyuruh raksasa itu memasukkan simpai pada lutut dan siku kerana dikatakan dapat mengubati sakit-sakit badannya. Raksasa tidak dapat bergerak, lalu Tuan Syeikh Alam di Rimba naik ke kepala raksasa itu dan mencakar mata raksasa itu dengan kuku kakinya sehingga pecah:

Maka Tuan Shaikh 'Alam di-Rimba pun memasokkan-lah simpai itu pada siku dan lutut gergasi itu. Sa-telah sudah, dimasokkan-nya sa-kali lagi segala simpai itu, sehingga tiada-lah dapat raksasa itu bergerak lagi oleh sangat sesak-nya itu. Kemudian Tuan Shaikh 'Alam di-Rimba pun berkata, "Hai raksasa, chuba putuskan simpai ini supaya baik dan puleh sa-mula tuboh tuanhamba seperti dahulu dengan berkat wali Alah yang keramat dan baginda "Ali dan supaya beroleh gagah perkasa tuan-hamba seperti masa muda dahulu."

(Hikayat Pelandok Jenaka: 64)

Dalam kisah ini, pelanduk tidak teragak-agak untuk berdepan dengan raksasa yang lebih besar daripadanya sekali gus menyerlahkan lagi ketokohannya sebagai pemimpin kepada seluruh isi rimba. Tipu muslihat menggunakan simpai ternyata berhasil menumbangkan raksasa dan meleraikan konflik yang membelenggu rakyatnya. Di samping itu, kepandaiannya dalam berpura-pura berjaya meyakinkan raksasa bahawa simpai tersebut dapat mengubati kesakitan badan serta boleh menjadikannya lebih muda dan gagah menambahkan lagi keberkesanan tipu muslihatnya. Penyelesaian konflik dalam kisah ini berjalan lancar melalui tipu muslihat yang dirancang rapi selain dipengaruhi oleh sifat kepimpinan pelanduk dan pengalamannya menyelesaikan konflik sebelum ini.

Kisah "Gajah Berperang dengan Semut" pula menceritakan peperangan yang tercetus disebabkan penghinaan raja gajah terhadap raja semut apabila raja gajah memperkecilkan keupayaan, saiz badan dan rupa raja semut. Dalam kisah ini, pelanduk yang terkenal dengan kehebatannya menyelesaikan konflik secara bijaksana dan penuh tipu muslihat hanya menjadi saksi kepada peperangan tersebut. Namun begitu, pelanduk tetap diberikan tempat sebagai pemimpin utama dalam kalangan penghuni rimba kerana setiap pertikaian atau peperangan yang berlaku wajib dimaklumkan terlebih dahulu kepadanya 
bagi mengelak penderhakaan. Konflik yang tercetus diselesaikan dengan pemikiran tajam raja semut apabila memerintahkan rakyatnya menggali sebuah lubang besar di tengah sebuah padang untuk memerangkap dan memperdayakan raja gajah. Dengan bersaksikan Tuan Syeikh Alam di Rimba, peperangan berlangsung dengan mudah sekali apabila raja gajah dan menterinya diperdaya lalu jatuh terpelosok masuk ke dalam lubang besar yang digali. Akhirnya, raja gajah dan menterinya mati disengat oleh bisa semut dan kerengga. Pada akhir kisah ini, pengarang menampilkan bahawa setiap kejahatan dan pengkhianatan pasti akan menerima pembalasan seperti yang dikatakan oleh Tuan Syeikh Alam di Rimba:

"Hai saudara-ku sakalian, inilah halnya. Tiada baik kita berbuat khianat dan aniaya kapada sa-suatu makhlok Allah subhanahu wata' ala itu. Sementang semut itu suatu binatang yang kechil, jangan-lah di-mudah-mudahkan dia. "Akal-nya tajam dan dapat di-balas-nya perbuatan orang kapada-nya."

(Hikayat Pelandok Jenaka: 76)

Sebagai tokoh pemimpin yang bijak dan disegani, Tuan Syeikh Alam di Rimba sentiasa menitikberatkan keharmonian dalam perhubungan dan sehabis daya berusaha mengelak daripada tercetusnya keganasan dengan tidak melakukan pengkhianatan dan menganiayai sesama makhluk. Dalam konflik yang berlaku kepada raja semut dengan raja gajah, dinyatakan bahawa raja gajah sering memperlekeh keupayaan raja semut kerana fizikalnya yang kecil. Walaupun begitu, raja semut dianugerahkan rahmat yang besar, iaitu fikiran yang tajam sehingga dapat mencari jalan menewaskan raja gajah yang terkenal dengan kekuatan fizikal. Kisah ini ternyata sangat berbeza daripada kisah-kisah yang dibincangkan lebih awal kerana strategi menggali lubang datangnya daripada raja semut dan bukannya daripada Pelandok. Ternyata raja semut telah menggunakan kurniaan akal fikiran yang diberikan oleh Allah SWT untuk membalas segala kezaliman raja gajah. Oleh itu, jelaslah bahawa sesiapa sahaja yang melakukan pengkhianatan dan menganiayai makhluk pasti akan menerima balasan Allah dengan sesuatu yang tidak terduga.

\section{KESIMPULAN}

Cerita rakyat seperti Hikayat Pelandok Jenaka yang digarap oleh pengarang zaman silam merupakan alat penyebaran ilmu pengetahuan serta pengajaran kepada masyarakat. Konflik yang berlaku dalam hikayat ini merujuk konflik 
yang berlaku antara dua buah pihak atau kumpulan yang masing-masing dibelenggu oleh pelbagai masalah dan persaingan dalam kehidupan mereka. Jika dilihat secara kasar, kisah-kisah dalam hikayat ini memfokuskan konflik masyarakat binatang di alam rimba tetapi disimbolikkan berdasarkan situasi sebenar kehidupan manusia yang tidak dapat dipisahkan daripada masalah, pertelingkahan mahupun perasaan dengki atau tidak puas hati. Dalam konteks ini, punca kepada tercetusnya konflik diselesaikan melalui kemahiran yang ditampilkan oleh watak utama, iaitu pelanduk jenaka atau gelarannya Tuan Syeikh Alam di Rimba. Sebagai tokoh pemimpin yang disegani dan dihormati, pelanduk menjadi harapan rakyatnya untuk menyelesaikan konflik berkaitan sesuatu perkara. Dalam beberapa kisah yang dibincangkan, pelanduk menjadi pencetus idea kepada penyelesaian konflik melalui kehebatannya membuat tipu muslihat. Tipu muslihat merupakan elemen pertama yang terhasil daripada pemikiran pelanduk diaplikasikan dengan baik sekali apabila musuh penyebab konflik yang membelenggu warganya berjaya dikalahkan. Maka, dapat dinyatakan bahawa pengarang zaman silam bijak menampilkan fenomena yang berlaku kepada kehidupan masyarakat manusia melalui cerita binatang dengan menampilkan kepimpinan pelanduk yang memiliki kebijaksanaan dan kemahiran/kebolehan menyelesaikan konflik secara tenang dan berwibawa sekali gus merefleksikan kearifan masyarakat Melayu.

\section{NOTA}

1. Lakum atau nama saintifiknya Vitis diffusa (dikenali juga sebagai ubi kertas) merupakan sejenis tumbuhan menjalar yang mudah dijumpai di negara kita terutamanya kawasan tepi sungai. Daunnya yang muda berwarna putih di bahagian bawahnya. Bahagian yang putih akan bertukar menjadi coklat keperangan setelah agak tua. Daunnya mempunyai bahagian tepi yang bergerigi. Lakum membiak melalui ubinya. Lakum juga merupakan antara tumbuhan yang mempunyai khasiat perubatan yang tinggi. Bahagian yang digunakan untuk perubatan ialah daun dan ubinya. Lakum digunakan untuk rawatan wanita selepas bersalin dan turut digunakan untuk mengubati bisul yang tidak mempunyai mata. Untuk rawatan selepas bersalin, beberapa helai daun lakum yang telah dikeringkan direbus, dan airnya yang telah suam diminum setiap hari. Proses pengeringan daun lakum yang hendak digunakan dalam perubatan perlu dilakukan di tempat teduh dan bukannya secara terus kepada cahaya matahari. Ubi lakum digunakan untuk merawat bisul dengan cara mengasah ubi tersebut pada buntut pasu dan dicampurkan dengan air dan disapu pada bahagian yang sakit lalu dibiarkan kering. Selain khasiat perubatan,buah lakum yangberwarna hitam juga merupakan umpan pancing yang paling digemari oleh spesies ikan sungai terutamanya ikan baung. 
2. Mengikut sebuah artikel akhbar Harian Metro yang ditulis oleh Mohd. Sabran Md. Sani pada 18/03/2014, menuba ikan menggunakan akar pokok tuba merupakan suatu tradisi masyarakat Melayu meracun ikan supaya memperoleh hasil tangkapan ikan dengan mudah dan cepat. Malah, kaedah menuba ikan dengan menggunakan akar tuba memudahkan ikan ditangkap berbanding menggunakan pukat atau jaring. Akar tuba ini sering digunakan untuk menangkap ikan sebab itu kadangkala akar tuba dikenali sebagai racun ikan. Menurut Razak Hj. Lajis dan Adenan Jaafar (1999), cara menggunakannya ialah dengan merendam atau mencampakkan akar tuba yang telah dihancurkan terlebih dahulu ke dalam punca air seperti anak air atau anak sungai. Beberapa ketika kemudian, ikan-ikan akan mabuk dan timbul di atas permukaan air. Akar tuba ini tidak dianggap begitu berbahaya kepada haiwan tetapi begitu toksik terhadap ikan.

\section{RUJUKAN}

Abdullah Hassan dan Ainon Mohd, 1997. Berkonflik dan Berunding. Kuala Lumpur: Utusan Publication.

Ahmad Murad Bin Nasruddin (peny.), 1955. Hikayat Pelandok Jenaka. Singapore: Malaya Publishing House Limited.

Belak, T., 1998. "Intergroup Conflict in the Workplace" dlm. http://www.mediate. com/articles/belak1.cfm (capaian 19 April 2014).

Coser, L. A., 1956. The Function of Social Conflict. New York: The Free Press.

http:/www.melur.com/myherba.asp?plant_id=267\&cat=herba. (capaian 23 Mei 2016).

Malike Brahim, 2008. Mengurus Konflik. Selangor: IBS Buku Sdn. Bhd.

Md. Yadi Said, 2006. Mengurus Konflik. Kuala Lumpur: PTS Professional.

Mohd Sabran Md. Sani. "Fungsi Unik Akar Tuba" dlm. Harian Metro, V4, 18 Mac 2014.

Mohd Taib Osman, 2007. "Sastera Rakyat/Lisan Melayu: Antara Pernyataan 'Local Genius’ dengan Ciri-ciri Kesejagatan” dlm. Rogayah A. Hamid \& Wardati Md. Sheriff(peny.). Tradisi Lisan Manifestasi Cendekiawan Melayu. Kuala Lumpur: Dewan Bahasa dan Pustaka.

Muhammad Haji Salleh, 2007. "Beberapa Catatan Pengalaman sastera Lisan" dalam Rogayah A. Hamid \& Wardati Md. Sheriff (peny.). Tradisi Lisan Manifestasi Cendekiawan Melayu. Kuala Lumpur: Dewan Bahasa dan Pustaka.

Noriah Taslim, 2007. "Sastera Lisan: Rencah Warisan dalam Pembentukan Tamadun dan Budaya" dlm. Rogayah A. Hamid \& Wardati Md. Sheriff (peny.). Tradisi Lisan Manifestasi Cendekiawan Melayu. Kuala Lumpur: Dewan Bahasa dan Pustaka.

Razak Hj. Lajis dan Adenan Jaafar, 1999. “Akar Tuba” dlm. http://www.prn.usm.my/ old_website/mainsite/bulletin/1999/penawa28.html (capaian 19 April 2014).

Safian Hussain, 1988. Glosari Istilah Kesusasteraan. Kuala Lumpur: Dewan Bahasa dan Pustaka. 